DOI: https://doi.org/10.31933/dijms.v2i3 Received: 30 September 2020, Revised: 25 November 2020, Publish: 22 January 2021

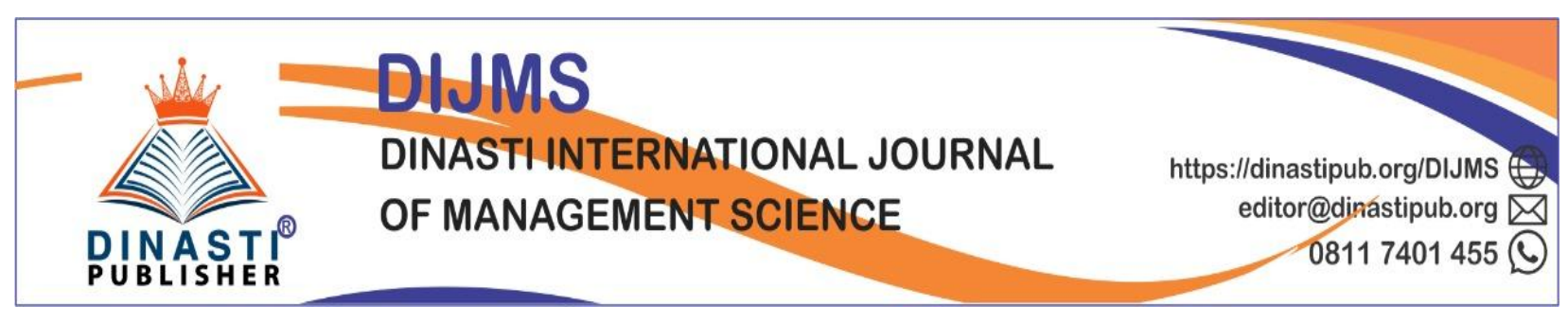

\title{
ORGANIZATIONAL CITIZENSHIP BEHAVIOUR THAT MEDIATED THOSE INFLUENCE OF TRANSFORMATIONAL LEADERSHIP AND ORGANIZATIONAL CULTURE TOWARDS EMPLOYEE PERFORMANCE AT XYZ ORGANIZATION
}

\author{
Aprilian Rahmawaty ${ }^{1}$, Singmin Johanes Lo ${ }^{2}$ \\ ${ }^{1)}$ Mercu Buana University, Jakarta, aprilianrahmawaty@gmail.com \\ ${ }^{2)}$ Mercu Buana University, Jakarta, singmin.johanes@ mercubuana.ac.id \\ Coresponding Author: Aprilian Rahmawaty
}

\begin{abstract}
Main purpose of this research was to explored An organizational citizenship behaviour's influenced that mediate the impact from transformational leadership and organizational culture towards employee performance at XYZ organizational. Research population was all employees from XYZ Organization, amounting to 113 employees. Sample method by non-probability sampling with saturated sampling as sampling technique so respondents chosen was 113 respondents. Data analysis method in this research used Structural Equation Model (SEM) with assist of Smart PLS version 3.2.9 program. These result indicated that transformational leadership and organizational culture has a positive and significant influence on employee performance Likewise to organizational citizenship behaviour.
\end{abstract}

Keywords: Transformational Leadership, Organizational Culture, Employee Performance, Organizational Citizenship Behavior.

\section{INTRODUCTION}

At this time each organization strives to reach rapid growth, continuous improvement, advantageousness and composing towards the future in facing worldwide competition. Besides that, organizations today were also competed in a changing environment and was very difficult to forecast all changes. This problem costing much time and money on changes in order to achieve high performance (Nikpour, 2017). Human resource development considers all employees as very important assets in determining part to achieving organizational goals. Every organization is required to optimize the role of human resources as optimally as possible in the sense that organization could create competitive advantage through effective and efficient human resource management in order to be able to compete in changing times. Effective leaders should be sound diagnoses and adopt to meet the demands of situations in 
which they operate. Different leadership used depend on employees, based on amount of rules, empowerment and decision-making power. As an outcome, employee performance is adversely influenced due to the lack of proper direction and strategic implementation on managing daily tasks in any organization.

Employee performance includes carrying out assigned tasks, meeting deadlines, employee competence and also effectiveness and efficiency in doing work (Mohamed et. al, 2018). A problem which often occurs due to the lack of strategic intervention from leadership specifically for certain situations to predict the problems at hand. Thus, this problem continues to affect employee performance. Leadership in organizations is very influential in shaping employee behavior towards organization. Good leadership in organization is the leadership who can raise enthusiasm and provide inspiration, so employees would feel inspired to follow and show good behaviour towards organization.

Researchers carried out an interviews with 2 (two) resource persons, which on 2 (two) subdivision heads in the field of employment. Informants said that the results of employee performance appraisal that were reported by employees each year did not match the reality in the field. The data for the last three years shows good performance reports where all stated that the average assessment score was more than 80 out of 100 . The following is the performance target data for employees in the XYZ Organization.

Table 1. XYZ Organization Employee Performance Targets

\begin{tabular}{ccccccc}
\hline & & \multicolumn{5}{c}{ Behaviour } \\
\cline { 3 - 7 } Year & SKP & Service Orientation & Integrity & Commitment & Discipline & Cooperation \\
\hline 2017 & 88,01 & 81,78 & 78,63 & 82,81 & 81,93 & 81,58 \\
\hline 2018 & 89,52 & 82,11 & 79,01 & 83,19 & 82,37 & 83,01 \\
\hline 2019 & 89,41 & 82,02 & 81,95 & 83,06 & 82,17 & 82,96 \\
\hline
\end{tabular}

Source: Employment Data at XYZ Organization

The resource person were explained that this was not appropriate, as happened in the field where employees did not have an understanding of the work delegated so they were unable to meet the set of standards and the completion of tasks which not completed on time. According to the information this is caused by weak voluntary behavior or what is commonly called OCB. The resource person explained that OCB has an important role in building good performance, but employees are reluctant to help colleagues and were reluctant to sacrifice personal interests for the benefit of the team. From these relationships between employee performance and $\mathrm{OCB}$, the speakers concluded that transformational leadership and organizational culture act as crucial part in OCB weakness that also has an influence over employee performance. More specifically, the resource person said that the needs of transformational leadership who has a vision and mission for the future and able to adjust and adapted the changes in organization, such as leaders who incapable to become an employee role models, who have not been able to encourage employee enthusiasm at work and leaders who have not encouraged employees to use their innovative thinking. The resource person were explained that organizational culture in xyz organization was not positive enough, the employees felt to have not shown attention to the details of work, the organizational activities were only for formality reports, not really for the development or progress of organization.

This research links to performance and leadership, organizational culture, and OCB in overall work of employees to reach those success. So needs lots of efforts made to improve organizational performance which starts in improving employee performance. Therefore, those 
understanding in organizational behaviour is very important to improve performance. Organizational management certainly separated from managerial aspects which are closely related to organizational activities, which one of that related to leadership, organizational culture, organizational citizenship behaviour (OCB) and employee performance.

According to these phenomena that occurs and compare to previous research on leadership, organizational citizenship behaviour and employee performance, seems that there has difference in research (gap research). Therefore, it is very interesting to conduct the research entitled to "Organizational Citizenship Behaviour that mediated Those Influence of Transformational Leadership and Organizational Culture towards Employee Performance at XYZ Organization".

\section{LITERATURE REVIEW \\ Transformational Leadership}

Siswatiningsih et. al (2018) was defined as transformational leadership based on the influence and relationships of the leader with followers or subordinates. The notions of transformational leadership combined the developed ideas in a character, style and contingency approach. According to Bass and Avolio (1985:14) in Soegiarto (2016:320) there are four elements that exist in transformational leadership, such as ideal influence, individual consideration, inspirational motivation and intellectual stimulation.

\section{Organizational Culture}

According to Sasingkelo et. al (2016) organizational culture is a shared belief value that underlies agency identity and agreement with members in the organization so as to facilitate the birth of a broader agreement for individual interests. Organizational culture becomes the controller and direction in shaping human attitudes and behavior who involve themselves in organizational activities. Pacanowsky and Trujillo (2009) in Badeni (2013:224) state that organizational culture has seven essential characteristics, which is innovation and risk taking, attention to detail, outcome orientation, people orientation, team orientation, aggressiveness, and stability.

\section{Organizational Citizenship Behaviour}

Based on Nugraha and Adyani (2018) OCB is a unique aspect of individual activities at work. Organizations will be successful if employees not only do their main tasks but also want to do extra tasks such as cooperating, helping, giving advice, participating actively, providing extra services to service users and willing to use their work time effectively. According to Organ (2015) in Lestari and Ghaby (2018) there are five dimensions that could be used to measure organizational citizenship behaviour (OCB), such as altruism, conscientiousness, sportmanship, courtesy and civic virtue.

\section{Employee Performance}

According to Shaleh (2018:57) employee performance as result of an employee's work during specific times compared to diverse chance, for example standards, targets, goals or criteria which have been determined in advance and have been mutually agreed. The level of employee performance is a measure of the efficiency and effectiveness of an organization in achieving predetermined goals. Bernardin and Russel (2013) in Yusniar (2016) stated that there 
are 6 criteria for assessing employee performance, which is quality, quantity, timeliness, cost effectiveness, need for supervision, and interpersonal impact.

\section{Conceptual Framework}

Transformational leadership and organizational culture are one of component or variables that could affect employee performance and organizational citizenship behaviour. The research results from Yusniar (2016) and Sasingkelo et. al (2016) were stated that organizational culture has an influence on employee performance. Meanwhile, the research results of Nugraha and Adnyani (2018); Husodo (2018) and Maulani et. al (2015) stated that organizational culture has a positive and significant impact on organizational citizenship behaviour. From these conceptual framework and hypothesis development above, the research model that could be described as follows:

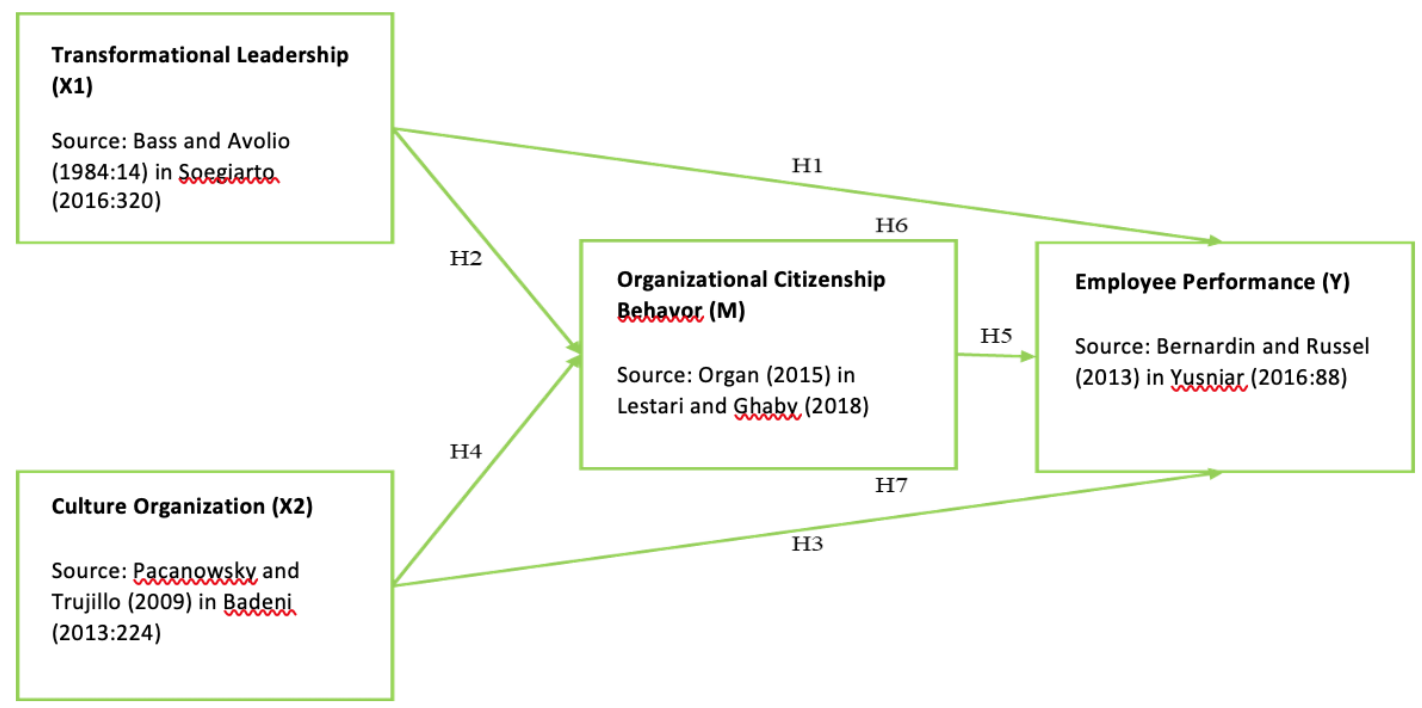

Figure 1. Research Conceptual Framework Model

\section{Hypothesis}

These hypothesis will be formulated as follows:

H1: Transformational leadership had significant influence on employee performance.

$\mathrm{H} 2$ : Transformational leadership had significant impact on organizational citizenship behaviour.

H3: Organizational culture had an influence towards employee performance.

H4: Organizational culture had an impact over organizational citizenship behaviour.

H5: Organizational citizenship behaviour had significant influence over employee performance.

H6: Transformational leadership had significant influence on employee performance that mediated by organizational citizenship behaviour.

H7: Organizational culture had significant influence on employee performance which mediated by organizational citizenship behaviour. 


\section{RESEARCH METHODS}

These research methods used quantitative methods with explanatory research approaches. Research population was total workers at XYZ Organization, amounting to 113 employees. The use of non-probability sampling as sample method and carried out by census sampling, until it reduced to 113 respondents. This research used a Structural Equation Model (SEM) approach by calculating model using Smart PLS version 3.2.9 program to estimated the intensity of each research variable and the structural model analyze data and research hypothesis.

\section{RESULTS AND DISCUSSION Descriptive Analysis of Respondents}

Based on the characteristics of 113 respondents, it was found that the majority of respondents who were employees at XYZ Organization were male $(53.1 \%)$ aged between 31 41 years $(56.6 \%)$ had an undergraduate education $(48.7 \%)$, and had working period between 6 10 years (41.6). This illustrated that the majority of respondents were men who have broad insight and have worked in the XYZ Organization for long period time, so they know the criteria / work targets that should be done in order to achieve organizational goals.

\section{Outer Model Measurement}

Based on convergent validity analysis, the first test result shows that the KT4 indicator has a loading factor value of $0.591<0.7$, so the indicator was removed from the model and a second test is necessary. In the second test, it was found that all the indicators in these research variables (transformational leadership, organizational culture, organizational citizenship behavior and employee performance) had a loading factor value between 0.701 to 0.936 , so it can be said that it was valid $(>0.7)$.

According to the value of Cronbach's alpha coefficient and composite reliability from its independent variables has value between 0.914 to 0.978 , so it could be said it was reliable (> $0.7)$.

\section{Inner Model Measurement}

Path coefficients were calculated by SmartPLS bootstrap and it outcomes were described as in Table 2 below.

Table 2. Path Coefficient value and P-Values (Direct and Indirect Influences)

\begin{tabular}{lccc}
\hline & $\begin{array}{c}\text { Original } \\
\text { Sample }(\mathrm{O})\end{array}$ & $\begin{array}{c}\text { T Statistics } \\
(|\mathrm{O} / \mathrm{STDEV}|)\end{array}$ & P Values \\
\hline Transformational Leadership -> Employee Performance & 0.317 & 2.964 & 0.003 \\
\hline Transformational Leadership -> OCB & 0.209 & 2.586 & 0.010 \\
\hline Organizational Culture -> Employee Performance & 0.307 & 2.944 & 0.003 \\
\hline Organizational Culture -> OCB & 0.610 & 7.095 & 0.000 \\
\hline OCB -> Employee Performance & 0.340 & 2.953 & 0.003 \\
\hline $\begin{array}{l}\text { Transformational Leadership -> OCB -> Employee } \\
\text { Performance }\end{array}$ & 0.071 & 2.355 & 0.019 \\
\hline Organizational Culture -> OCB -> Employee Performance & 0.207 & 2.629 & 0.009 \\
\hline
\end{tabular}


The results on Table 2 showed that: transformational leadership had significant and positive impact on employee performance and OCB; organization culture had significant and positive influence on employee performance and OCB. However, Path analysis result shows that indirect effect from transformational leadership and organizational culture towards employee performance that mediate role of OCB was smaller than the direct one.

\section{$\mathbf{R}^{2}$ Evaluation, F-Test, and Goodness of Fit (GoF) Index}

The $\mathrm{R}^{2}$ result value was 0.714 towards employee performance variable and 0.575 towards OCB. The $\mathrm{R}^{2}$ value indicated that the level of persistence of the exogenous variables (transformational leadership and organizational culture) towards the endogenous variables seems to have quite a high.

The performance validation for the combined inner model and outer model (GoF) was 0.673. Based on these results, it can be said that it was good cause of 9 Goodness of Fit Index (GoF) value is more than 0.36 (a maximum score of GoF).

\section{Loading Factor Analysis}

Based on these examine results, the highest inner loading factor value in transformational leadership variable shows in KT2 indicator related to organizational leaders who become role models for employees. The highest inner loading factor value in organizational culture variable shows in the BO4 indicator which related to the leader's expectations in hopes that employees will show the results of their work analysis. The highest inner loading factor value in the OCB variable shows in the OCB9 indicator that related to employees attitude who needs to prioritize the interests of the team above their personal interests. While the highest inner loading factor value in employee performance variables shows in the KP4 indicator that relates to employees who always come on time.

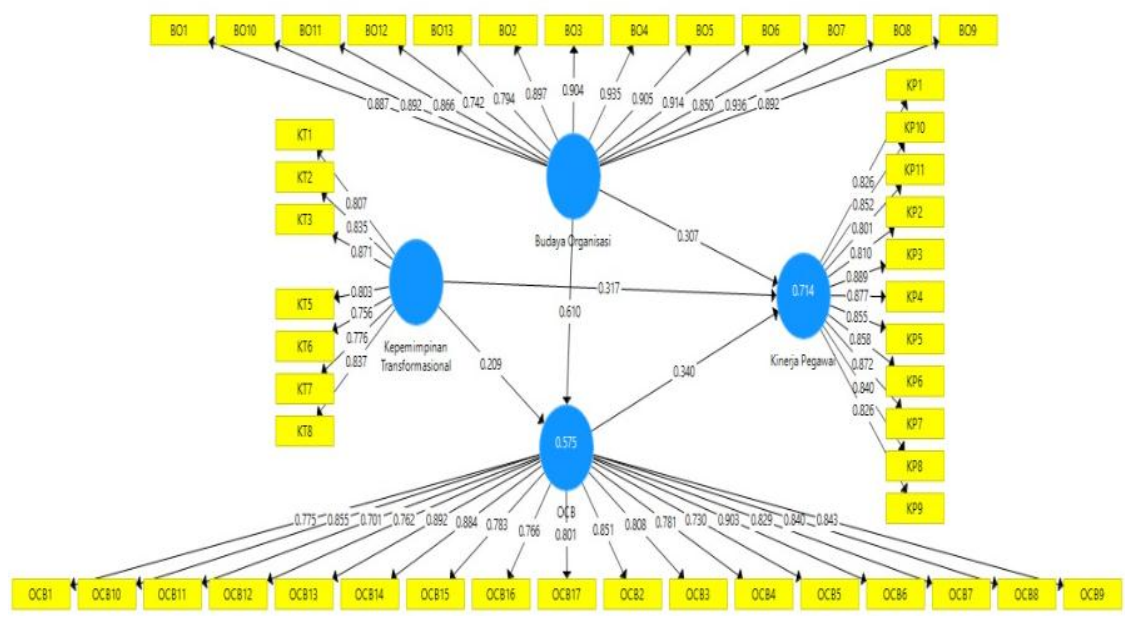

Figure 2. Bootstrapping the Inner Model

\section{Discussion}

The first hypothesis shows that transformational leadership had impact towards employee performance at XYZ Organization. The results from these research were in line with research by Dewi et. al (2018); and Andriani (2016) who found that transformational leadership had 
impact over employee performance, meaning that the better the implementation of transformational leadership has results in an increase of employee performance.

The second hypothesis shows that transformational leadership had influence over organizational citizenship behaviour at XYZ Organization. These research results were in line with Dewi et. al (2018) and Prahesti et. al (2017) defined that transformational leadership given positive impact towards OCB. The greater the implementation of transformational leadership in providing motivation, encouraging employees to be more innovative and creative and concern to employee development and job performance, then the higher OCB will get as a result.

The third hypothesis shows that organizational culture had influence towards employee performance at XYZ Organization These research results supported the research from Thuku et. al (2016); and Sasingkelo et. al (2016) who found that organizational culture has a positive and significant impact on employee performance. This demonstrate if leaders could influence subordinates through organizational culture, because the behavior of organizational members is strongly influenced by organizational culture. Meaning that there is a very good influence in organization where there is a mutual commitment both organizational culture and leadership to influence employee performance.

The fourth hypothesis shows that organizational culture has an impact on organizational citizenship behavior at XYZ Organization. The results by Husodo research (2018) described that organizational culture has a positive and significant impact towards organizational citizenship behavior (OCB). Its because organizations that have a high organizational culture could increase their influence to increase the human resources and organizational culture could change the behavior of employees to work beyond their ability, and contribute to other employees. These results were in line with research by Nugraha and Adnyani (2018) and Maulani et. al (2015) who found that organizational culture has a positive and significant impact on OCB.

The fifth hypothesis shows that organizational citizenship behavior has an impact towards employee performance at XYZ Organization. This research was in line with results from previous research and consistent with the research results by Lestari and Ghaby (2018); and Prahesti et. al (2017) which said that OCB has a positive and significant impact on employee performance. Meaning that the greater the additional role played by employees at XYZ Organization, the greater the employee's intention to improve performance.

The sixth hypothesis shows that transformational leadership has an impact towards employee performance which mediated by organizational citizenship behavior at XYZ Organization. These results were in line with the findings made by Prahesti et.al. (2017) which described if the OCB mediates partially and positively and has a significant relationship between transformational leadership and employee performance. This indicates that employee behavior in the organization play crucial part in organization's success

The seventh hypothesis shows that organizational culture has an impact towards employee performance that mediated by organizational citizenship behavior at XYZ Organization. These results supported the research result from Maulani et.al. (2015) which said those influence between organizational culture variables on employee performance through organizational citizenship behavior. That proven if the need of organizational culture as basic of rules and values to be adhered and applied by employees in realizing the organizational goals. 


\section{CONCLUSION AND SUGGESTION Conclusion}

Based on these test results which have been carried out through statistical calculations, the conclusions from these research results it could be served as follows:

1) Transformational leadership had positive and powerful impact towards employee performance at XYZ Organization.

2) Transformational leadership had positive and substantial impact upon organizational citizenship behaviour at XYZ Organization.

3) Organizational culture had positive and significant control across employee performance at XYZ Organization.

4) Organizational culture had positive and substantial impact on organizational citizenship behaviour at XYZ Organization.

5) Organizational citizenship behaviour had positive influence on employee performance at XYZ Organization.

6) Transformational leadership had positive and powerful force on top of employee performance that mediated by organizational citizenship behaviour at XYZ Organization.

7) Organizational culture had positive and significant impact towards employee performance that mediated by organizational citizenship behavior at XYZ Organization.

\section{Suggestion}

According to these research results, the researchers advise could be drawn on these following sentences are.

\section{For Organizational Management}

It is suggests that the management need to concern about the leadership attitudes that they need to give more attention to employees and provide opportunities for employees to express their desires and encourages their motivation to get what they want. It is suggested for the organization to improve by creating leaders who could become role models for employees and get lots of respect. It is advise that the management consider the existence of its employees as members of work groups and carry out good work interactions so the relationship between colleagues would feel more harmonious and also it suggests to the agencies to put more effort into doing certain work methods, then work results were in accordance with the standards or qualifications determined by the organization.

\section{For Next Further Research}

For next further Research For next further research needs to carry out by adding several other independent variables such as training, attitudes and competencies, which of these variables would have an impact to the results related to factors which has strong determine on employee performance. Then, this analysis could be carried out by adding moderating variables likes motivation, work satisfaction also commitment, with aim of gaining more information on which groups are more likely needs an employee development to supporting their performance. 


\section{REFERENCE}

Andriani, D 2016, "Pengaruh Gaya Kepemimpinan Transformasional, Budaya Organisasi Dan Lingkungan Kerja Terhadap Kinerja pegawai PT. "X " Sidoarjo", Jurnal Bisnis, Manajemen \& Perbankan, Vol. 2, No. 2, hh. 121-140.

Badeni 2013, Kepemimpinan dan Perilaku Organisasi, Alfabeta, Bandung.

Dewi, N.K, Gunawan, Y \& Vira, S.A 2018, "Pengaruh Kepemimpinan Transformasional Terhadap Kinerja pegawai Bumn Di Kota Bandung Dengan Organizational Citizenship Behaviour Sebagai Variabel Moderasi (Studi PT. Kimia Farma (Persero) Tbk dan PT. Bio Farma (Persero)", Social Science Education Journal, Vol. 5, No. 1, hh. 87-103.

Husodo, Y.R 2018, "Pengaruh Budaya Organisasi Terhadap Organizational Citizenship Behavior (OCB) Dengan Kepuasan Kerja Sebagai Variabel Intervening Pada PT Jatim Indo Lestari", Jurnal AGORA, Vol. 6, No. 1, hh. 1-8.

Lestari, E.R \& Ghaby, N.K 2018, "Pengaruh Organizational Citizenship Behavior (OCB) terhadap Kepuasan Kerja dan Kinerja pegawai”, Industria: Jurnal Teknologi dan Manajemen Agroindustri, Vol. 7, No. 2, hh. 116-123.

Maulani, V.H, Widiartanto \& Dewi, R.S 2015, "Pengaruh Budaya Organisasi dan Komitmen Organisasi Terhadap Kinerja pegawai Melalui Organizational Citizenship Behavior (OCB) Sebagai Variabel Intervening (Studi Kasus pada Pegawai PT Masscom Graphy Semarang)", Jurnal Ilmu Administrasi Bisnis, Vol. 4, No. 3, hh. 1-12.

Mohamed, H.A, Datche, E \& Kisingu, T 2018, "Effect of Leadership Styles on Employee Performance in The Somali National Civil Service Commission", International Journal of Novel Research in Humanity and Social Sciences, Vol. 5, Issue. 3, hh. 56-69.

Nikpour, A 2017, "The Impact of Organizational Culture on Organizational Performance: The Mediating Role of Employee's Organizational Commitment", International Journal of Organizational Leadership, Vol. 6, hh. 65-72.

Nugraha, I.P.S \& Adnyani, I.G.A 2018, "Pengaruh Budaya Organisasi, Komitmen Organisasi, dan Kompetensi Terhadaporganizational Citizenship Behaviour Pada Setda Kota Denpasar", E-Jurnal Manajemen Unud, Vol. 7, No. 1, hh. 1-28.

Prahesti, D.S, Riana, I.G \& Wibawa, I.M.A 2017, "Pengaruh Kepemimpinan Transformasional Terhadap Kinerja pegawai Dengan Ocb Sebagai Variabel Mediasi”, E-Jurnal Ekonomi dan Bisnis Universitas Udayana, Vol. 6, No. 7, hh. 2761-2788.

Sasingkelo, R, Kojo, C \& Rumokoy, F.S 2016, "Pengaruh Gaya Kepemimpinan dan Budaya Organisasi Terhadap Kinerja Keryawan Pada PT. Horiguchi Sinar Insani”, Jurnal Riset Ekonomi, Manajemen, Bisnis dan Akuntansi, Vol. 4, No.4, hh. 2107 - 2114.

Shaleh, M 2018, Komitmen Organisasi Terhadap Kinerja Pegawai, Penerbit Aksara Timur, Makassar.

Siswatiningsih, I, Raharjo, K \& Prasetya, A 2018, "Pengaruh Kepemimpinan Transformasional dan Transaksional Terhadap Budaya Organisasi, Motivasi Kerja, Komitmen Oganisasional dan Kinerja pegawai”, Jurnal Bisnis dan Manajemen, Vol. 5, No. 2, hh. 146-157.

Soegiarto, M 2016, "Pengaruh Kepemimpinan Transformasional Terhadap Kinerja pegawai Pada CV. Norton Surabaya", Jurnal AGORA, Vol. 4, No. 2, hh. 320-327.

Thuku, R.W, Abiero, I.O \& Juma, D 2016, "Influence of Organisational Culture on Employee Performance: A Case Study of East African Breweries Limited", International Journal of Science and Research, Vol. 6, No. 14, hh. 1500-1506.

Yusniar 2016, "Pengaruh Budaya Organisasi Terhadap Kinerja Melalui Motivasi di Sekretariat Daerah Kabupaten Aceh Utara", Journal of Economic Management \& Business, Vol. 17, No. 1, hh. 85-104. 